\title{
Ectopic Tooth in the Maxillary Antrum- A Mini Review
}

\author{
Mohammad Adel Helmy* \\ Faculty of Dentistry, Cairo University, Egypt
}

Submission: April 16, 2017; Published: April 21, 2017

*Corresponding author: Mohammad Adel Helmy, BDS, Faculty of Dentistry, O6U, MDS Faculty of oral and dental medicine, Cairo University, Egypt, Email: drmah84@gmail.com

\section{Abstract}

Ectopic eruption of teeth in non-dental sites is a rare phenomenon; It may be symptomless but is more commonly associated with inflammatory symptoms. It can present in a variety of ways such as chronic or recurrent sinusitis, sepsis, nasolacrimal duct obstruction, headaches, ostiomeatal complex disease and facial numbness. The treatment of choice is surgical excision which is mostly carried out with Caldwell-Luc approach, even though endoscopic approach is being reported.

Keywords: Ectopic tooth; Maxillary sinus; Caldwell-lac

\section{Introduction}

The development of deciduous tooth starts in the sixth week of intra-uterine life with the development of dental lamina. Then the ectodermal layer proliferation begins to form the permanent dentition between 5 th and 10 th post natal months [1]. It is a multistep event in which interaction between the oral epithelium and the underlying mesenchymal tissue plays a vital role. Abnormal interaction at any step may result in ectopic tooth development and eruption. Ectopic eruption of a tooth within the dentate region is often seen in clinical practices, which are more common in mandible, and among females. Incisors, canines and premolars are the most affected teeth [2]. But such a condition in a non-dentate area like maxillary sinus is very rare. Due to its rarity, the incidence deserves to be added to the literature and discussed. Maxillary teeth in maxillary sinus may precipitate sinusitis or sometimes result in ophthalmic symptoms also [3]. Tooth eruption process is, in most cases, a passive one but an abnormal tissue interaction during odontogenesis may result in ectopic tooth development and eruption [4]. The displacement of the tooth may also be due to pressure caused by a cystic enlargement. Another etiology may include developmental disorders such as cleft palate, trauma causing displacement of the teeth, maxillary infection, crowding, genetic factors, and high bone density $[5,6]$.

\section{Methodology}

Water's view, OPG, and lateral cephalogram are simple and inexpensive projections for radiographic evaluation of an ectopic tooth in the maxillary sinus. Though expensive, CT and MRI certainly have an edge over conventional radiographs [7]. CT scan provides superior bony detail, helps in determination of the size and extent of the lesion, and is useful to distinguish a maxillary lesion of antral origin from an extraantral lesion [8]. Bonder et al. [9] studied 12 patients with teeth in the maxillary sinus by plain film radiography (PFR) and by CT with a dental software program. He found that CT was superior to PFR to determine proximity of the tooth to the sinus wall or its ankylosis, proper surgical planning (crestal incision or Caldwell-Luc approach), as well as prediction of prognosis or complications.

The treatment of an ectopic tooth in the maxillary sinus is removal, as it may lead to cyst formation if left untreated [10]. The traditional approach is Caldwell-Luc procedure, which allows a direct view into the maxillary sinus [7]. In a study of 30 cases, the most common approach was Caldwell-Luc procedure (18 cases), five patients were treated with endoscopic sinus surgery, 3 with marsupialization, 2 with crestal incision, and enucleation method was used for only one patient [11] Somayaji et al. [12] extracted a tooth with endoscopic procedure through sublabial approach and concluded that it enabled better exposure, good illumination, and magnification resulting in less morbidity, meticulous surgery, and faster postoperative recovery. However no direct comparative study was performed in the presentation.

\section{Discussion}

Ectopic eruption of a tooth within the dentate region is often seen in clinical practice, which is more common in mandible but such a condition in a nondentate area like maxillary sinus is very rare $[13,14]$. Ectopic and supernumerary teeth have also been described in nondental and nonoral sites such as the 
mandibular condyle, coronoid process, orbit, palate, nasal cavity, nasal septum, and the chin [15]. Beriat et al. [11], in their review of ectopic teeth in maxillary sinus, reported 18 molars, of which 17 were third molars, 5 canine, 3 supernumerary, 1 odontoma, 1 tooth-like structure, and only 1 premolar. The problem of a tooth or root in the maxillary antrum can be a perplexing one. An extensive dentigerous cyst may surround the tooth or root and a fistula, either antro-cutaneous, [16] or antro-oral, [17] can develop. Maxillary sinus abnormalities occur in asymptomatic individuals and only X-ray of the antra reveals a cyst or tooth or both [18].

However, most maxillary cysts arise as a result of defects in embryological development which occur either as abnormalities in the fusion of facial processes or abnormal development of the dental follicle [19]. Foreign bodies, metallic or non-metallic, may also lay dormant in the maxillary sinus. Maxillary teeth in maxillary sinus may be discovered accidentally, precipitate sinusitis, or sometimes result in ophthalmic symptoms [14]. Somayaji et al. [12] in the report of a tooth in the maxillary antrum reported nasal obstruction, discharge, and minimal fullness in right nasolabial area. Inflammatory reaction to the tooth in the antrum, which is foreign to the location, appears to be the commonest presenting symptom. About half of the thirty cases of teeth in the maxillary antrum in Beriat's description also presented with inflammatory symptoms. Foreign bodies (rhinoliths), infections like syphilis, tuberculosis, or fungal infections with calcification, benign lesions such as hemangioma, osteoma, enchondroma, calcified polyp, and dermoid cysts or tumors, and malignant lesions such as chondrosarcoma and osteosarcoma must be considered in the differential diagnosis of ectopic teeth [11].

Many surgical approaches have been reported in the literature including the endoscopic removal of such ectopic teeth and associated lesions. Di Pasquale P and Shermetaro C, [20] used a nasal endoscope to create a middle meatal antrostomy and deliver the ectopic tooth and its cystic contents. The endoscopic techniques are being used for removal of an intranasal ectopic tooth [21] obstructing nasal cavity and ectopic maxillary third molar obstructing osteomeatal complex [22]. Postoperative follow-up with radiographic examination at regular intervals is mandatory to rule out any recurrence.

\section{Conclusion}

Ectopic tooth in the maxillary sinus is a rare phenomenon, whenever noticed it should be examined and diagnosed properly. Treatment done either with Caldwell-Luc approach or endoscopic approach which is associated with lesser operative and post-operative morbidity.

\section{References}

1. Thesleff I, Nieminen P (1996) Tooth morphogenesis and cell differentiation. Curr Opin Cell Biol 8: 844-850.
2. Erkmen N, Olme S, Onerci M (1988) Supernumerary tooth in the maxillary sinus: Case report. Aust Dent J 43(6): 385-386.

3. Ray B, Bandopadhyay SN, Das D, Adhikary B (2009) A rare cause of nasolacrimal duct obstruction: Dentigerous cyst in maxillary sinus. Indian J Ophthalmol 57: 465-467.

4. Srinivasa Prasad T, Sujatha G, Niazi TM, Rajesh P (2007) Dentigerous cyst associated with an ectopic third molar in the maxillary sinus: a rare entity. Indian J Dent Res 18(3): 141-143.

5. Smith RA, Gordon NC, de Luchi SF (1979) Intranasal teeth: report of two cases and review of the literature. Oral Surgery, Oral Medicine, Oral Pathology 47(2): 120- 122.

6. Spencer MG, Couldery AD (1985) Nasal tooth. J Laryngol Otol 99(11): 1147-1150.

7. Kasat VO, Karjodkar FR, Laddha RS (2012) Cyst associated with an ectopic third molar in the maxillary sinus: a case report and review of literature. Contemporary Clinical Dentistry 3(3): 373-376.

8. Han MH, Chang KH, Lee CH, Na DG, Yeon KM, et al. (1995) Cystic expansile masses of the maxilla: differential diagnosis with CT and MR. AJNR Am J Neuroradiol 16(2): 333-338.

9. Bonder L, Tovi F, Bar-Ziv J (1997) Teeth in the maxillary sinus- imaging and management. J Laryngol Otol 111: 820-824.

10. Srinivasa Prasad T, Sujatha G, Niazi TM, Rajesh P (2007) Dentigerous cyst associated with an ectopic third molar in the maxillary sinus: a rare entity. Indian J Dent Res 18(3): 141-143.

11. Beriat GK, Beriat NC, Yalcinkaya E (2011) Ectopic molar tooth in the maxillary sinus. A case report. Clinical Dental Research 35: 35-40.

12. Somayaji KSG, Rajeshwary A, Nalapad Abdulla M, Ramlan S (2013) Ectopic premolar tooth in the maxillary sinus: a case report and review of literature. Archives of Medicine and Health Sciences. 1(1): 48-51.

13. Erkmen N, Ölmez S, Önerci M (1998) Supernumerary tooth in the maxillary sinus: case report. Aust Dent J 43(6): 385-386.

14. Ray B, Bandyopadhyay S, Das D, Adhikary B (2009) A rare cause of nasolacrimal duct obstruction: dentigerous cyst in the maxillary sinus. Indian Journal of Ophthalmology 57(6): 465-467.

15. Saleem T, Khalid U, Hameed A, Ghaffar S (2010) Supernumerary, ectopic tooth in the maxillary antrum presenting with recurrent haemoptysis. Head and Face Medicine 6(1, article 26).

16. Agarwal PN (1966) An extensive dentigerous cyst with antrocutaneous fistula. J Laryngol Otol 80: 544-547.

17. Setiya M (1965) A dentigerous cyst with antro-oral fistula. J Laryngol Otolo 79: 75-79.

18. Fascenelli FW (1969) Maxillary sinus abnormalities: Radiographic evidence in an asymptomatic population. Arch Otolaryngol 90: 190193.

19. Beekhuis GJ, Watson TH (1967) Midfacial cysts. Arch Otolaryngol 85:62-66.

20. Di Pasquale P, Shermetaro C (2006) Endoscopic removal of a dentigerous cyst producing unilateral maxillary sinus opacification on computed tomography. Ear Nose Throat J 85(11): 747-748.

21. Kim DH, Kim JM, Chae SW, Hwang SJ, Lee SH, et al. (2003) Endoscopic removal of an intranasal ectopic tooth. Int J Pediatr Otorhinolaryngol 67(1): 79-81.

22. Hasbini AS, Hadi U, Ghafari J (2001) Endoscopic removal of an ectopic third molar obstructing the osteomeatal complex. Ear Nose Throat J 80(9): 667-670. 
(C) This work is licensed under Creative CC) Commons Attribution 4.0 License BY DOI: $10.19080 /$ GJO.2017.07.555701
Your next submission with Juniper Publishers will reach you the below assets

- Quality Editorial service

- Swift Peer Review

- Reprints availability

- E-prints Service

- Manuscript Podcast for convenient understanding

- Global attainment for your research

- Manuscript accessibility in different formats ( Pdf, E-pub, Full Text, Audio)

- Unceasing customer service

Track the below URL for one-step submission https://juniperpublishers.com/online-submission.php 